Розділ І. Ціннісні орієнтири духовно-інтелектуального виховання, розвиток духовно-інтелектуальних якостей особистості в умовах співпраці й інклюзії

\title{
ВИХОВНИЙ ЗМІСТ МУЗИКОТЕРАПІЇ
}

\section{Маркіна Н. В.}

здобувач третього (освітньо-наукового) рівня вищої освіти кафедри освітології та інноваційної педагогіки, Харківський національний педагогічний університет імені Г. С. Сковороди, м. Харків, Україна

У роботі розкриваються вплив мистецтвва та музики на людину в лікувальній та педагогічній практииі. Уточнюються поняття музикотерапія, ї̈ методи, форми, засоби та як вона впливає на емочійнопочуттєву сферу і фізіологічний стан людини. Розглядаються техніки музикотерапії які застосовують на заняттях.

Ключові слова: музикотерапія, зміст музикотерапії, виховання музикою, позитивні емоиії.

The paper highlights the impact of art and music on people medical and pedagogical practice. The concept is revealed / musictherapy, methods, forms, means and how it affects the emotional sensory sphere and physiological state of people. Techniques are considered musictherapy used in the classroom.

Key words: musictherapy, the content of musictherapy, education of music, positive emotions.

Використання музики в лікувальній та педагогічній практиці має багатовікову історію. Такі відомі античні філософи як Аристотель, Піфагор, Платон, звертали увагу на цілющу силу музики. Вони вважали, що музика відновлює порушений порядок і втрачену гармонію, як окремої людини так і всього Всесвіту. Термін «музикотерапія» грецьколатинського походження і в перекладі означає «зцілення музикою» [2].

Наукові праці сучасних дослідників (Р. Вайноли, В. Гаврилюка, А. Голик, Г. Грищенко, І. Коршакової, І. Левченко, О. Мєдвєдєвої, С. Науменко) розкривають і обгрунтовують поліфункціональність та всебічність впливу на людину мистецтва загалом та музики зокрема. Деякі 3 них уважають, що музикотерапія є допоміжним засобом психотерапії, а інші визначають іiі як системне використання музики в лікуванні дітей; засіб оптимізації творчої та педагогічно-творчої роботи; найновішу психотехніку, що здатна забезпечити ефективне функціонування людини в суспільстві, гармонізувати їі життя [3, с.152].

Музикотерапія $є$ позитивним чинником становлення й розвитку гармонійної особистості через вплив на емоційно-почуттєву сферу, 
інтелектуальні здібності, психотерапевтичний і фізіологічний стан. Своїми формами, засобами, методами музикотерапія впливає на осіб iз соціальними, соматичними, психічними відхиленнями, виховує їх та готує до позитивної адаптації у нормальних життєвих умовах. Важливим для музикотерапії є те, що ми не тільки визнаємо можливість лікувального впливу творів музичного мистецтва, але й, використовуємо виховні можливості музики, за допомогою яких стало можливим цілеспрямовано і систематично впливати на особистість. Сутність музикотерапії ми бачимо в здатності викликати у людини позитивні емоції, які надають лікувальну дію на психосоматичні та психоемоційні процеси, мобілізують резервні сили, обумовлюють акумуляцію творчого потенціалу у всіх галузях мистецтва і життя в цілому [4].

Анжела Гельбак у навчально-методичному посібнику «Музикотерапія у роботі з дітьми з особливими освітніми потребами» зазначила такі техніки, що сьогодні застосовуються в музикотерапії, а саме:

- рухове розслаблення і злиття з ритмом музики;

- музично-рухові ігри і вправи;

- музична психосоматична релаксація;

- вокалотерапія;

- гра на музичних інструментах;

- рецептивне сприймання музики;

- музичне малювання;

- пантоміма;

- рухова драматизація під музику;

- музична розповідь;

- імпровізація;

- гра з лялькою та дихальні вправи з музичним супроводом [1, с. 37].

Отже, музикотерапія є позитивним чинником становлення й розвитку гармонійної особистості через вплив на емоційно-почуттєву сферу, психотерапевтичний і фізіологічний стан людини. Музикотерапія сприяє процесу збереження і зміцнення здоров’я, спрямованого на перетворення інтелектуальної й емоційної сфер особистості, підвищення ціннісного ставлення до власного здоров'я і здоров'я інших. Ефективний вплив музикотерапії на організм та психіку людини може бути успішним лише за умови доцільного використання комплексу відповідних методів. 
Розділ І. Ціннісні орієнтири духовно-інтелектуального виховання, розвиток духовно-інтелектуальних якостей особистості в умовах співпраці й інклюзії

\section{Список використаних джерел:}

1. Гельбак А. М. Музикотерапія як освітня інновація. Психологія: від теорії до практики. Інноваційні технології в роботі практичного психолога : матеріали між нар. наук.-прак. конф. (м. Суми, 7 черв. 2018 р.) Суми, 2018. С. $37-42$.

2. Колесникова Н. Пифагор: музыкотерапия и искусство музики. 2017. URL: http://culturolog.ru/index2.php?option=com_content\&task=view\&id=2780\& pop $=1 \&$ page $=0 \&$ Itemid=11 (дата звернення: 1.10 .2021$)$.

3. Кузмінська Л. Зміст і цілі музикотерапії в соціально-педагогічній роботі 3 дітьми. Український науковий журнал Освіта регіону: політологія, психологія, комунікації. 2011. № 5. С. 152.

4. Нестеренко О. І. Музикотерапія як засіб формування емоційного здоров’я дошкільників. 2019. URL: https://vseosvita.ua/library/muzikoterapia-akzasib-formuvanna-emocijnogo-zdorova-doskilnikiv-81466.html (дата звернення: 1.10.2021). 